\title{
Implications of water policy reforms for virtual water trade between South Africa and its trade partners: economy-wide approach
}

\author{
Rashid Hassan ${ }^{\mathrm{a}}$ and Djiby Racine Thiam ${ }^{\mathrm{b}}$ \\ ${ }^{a}$ Centre for Environmental Economics and Policy Analysis in Africa (CEEPA), Faculty of Natural and Agricultural Sciences, \\ University of Pretoria, Pretoria 0002, South Africa \\ ${ }^{b}$ Corresponding author. Centre for Development Research (ZEF), University of Bonn, Walter-Flex-Strasse 3, Germany \\ E-mail: dthiam@uni-bonn.de
}

\begin{abstract}
This paper employs an economy-wide framework to evaluate impacts of water and trade policy reforms in South Africa (SA) on virtual water flows. To pursue this analysis, the study derives net virtual water trade flows between SA and its partners to assess implications of recent trade agreements within the South African Development Community compared to economic cooperation with other major trading blocks (e.g. European Union, Asia, and Brazil, Russia, India and China (BRIC)). Recent trends in actual trade confirm model predictions that liberalization of water allocation would switch water from field crops to horticulture and promote growth in non-agricultural exports. The results suggest that it is necessary to introduce policies that enhance likely outcomes of liberalization promoting higher water use efficiency within irrigation agriculture such as increased adoption of more efficient irrigation methods (sprinkler, drip, etc.) as water becomes more expensive under wider open competition. Moreover, investment in higher water use efficiency and improved competitiveness of dryland agriculture therefore represent the sound economic options for strengthening the capacity to achieve food security objectives as the country strives to lower net water exports. Finally, careful coordination of trade and water policy reforms is another necessary challenge for SA's strive to manage a water stressed economy.
\end{abstract}

Keywords: Economy-wide modelling; Trade policy; Virtual water trade; Water policy

\section{Introduction}

Improving the economic efficiency of water use is a major challenge facing water stressed countries like South Africa (SA). To pursue this long-term strategic objective, such countries typically introduce various demand management measures and policies to direct water to their most economically productive uses and induce adoption of more efficient water use technologies and conservation practices. Combinations of a number of alternative market-based instruments and other regulatory 
measures have been applied in many countries with varying degrees of success in promoting efficient use and conservation of water resources (Dinar et al., 1997; Lange \& Hassan, 2006; IWMI, 2007). In addition to such in-country measures of water management and policy, trade in virtual water (VW) (water embodied in goods imported from and exported to other countries) affects demand and competition for water, and hence represents another way of influencing water conservation and allocation efficiency between countries. Virtual water trade (VWT) is the process by which countries (or regions) import water (virtually) from another country through importation of water-intensive products instead of using their own water to produce those goods. This helps reduce the demand for water in the importing country. Determination of VW flows between countries therefore allows policy-makers to find alternatives to re-balance water allocation between different sectors domestically and within economies of trading partners (Allan, 2001; Zimmer \& Renault, 2003).

Exploiting such differential in relative water abundance through trade follows the principles of comparative economic advantage that promote trade specialization, which dates as far back as Ricardo (1815) and Mill (1844). While trade flows and degree of specialization in production is a function of many other factors, trade policies that consider the water resource endowments differential can complement internal water reform measures in improving efficiency of use and allocation between competing domestic uses (Velázquez, 2007; Konar et al., 2011). Therefore, improving water management via VWT must be undertaken in a broader public policy context that involves all sectors that use water directly or indirectly, for productive and other purposes. Public policy influences the efficiency of water use and enhances nations' efforts to introduce complementary VWT policies through various pathways, particularly via interventions to correct distortions in the structure of economic incentives due to market and policy failures at farm and sector levels, domestic markets, and foreign trade regimes. Nevertheless, the question of to what extent internal water reforms enhance or contradict the objectives and impacts of VWT has so far received little attention in the water policy and trade literature.

Water resources management and policy in SA provide one typical example where the water sector has been undergoing radical policy reforms while simultaneously adjusting to major shifts in macroeconomic and trade policies over the recent past. Several institutional and policy reforms have been recently introduced to correct the structure of incentives and remove distortions causing major policy and market failures in the water sector (Shreiner \& Hassan, 2011). A good amount of research work assessing the impacts of these reforms has been undertaken both at sector level as well as economywide (Hassan et al., 2008). Conversely, little parallel effort has gone into analysis of how the structure of the country's international trade flows and policies has impacted VWT and in turn efficiency in domestic water allocation and use (Chapagain \& Hoekstra, 2003; Hoekstra \& Hung, 2005; Lange \& Hassan, 2006; Dabrowski et al., 2009). Most important is the fact that the two efforts have so far not been directly linked in terms of how consistent and enhancing or conflicting internal water policy reforms and VWT patterns have been in improving domestic water use and allocation efficiency. This is what the present study aims to contribute.

To achieve this objective, our study builds on the recent work of Hassan et al. (2008) and Hassan \& Thurlow (2011) that analyzed economy-wide implications of recent water policy reforms, and an earlier study by Lange \& Hassan (2006) that examined VWT in SA. Both studies employed economy-wide analyti-cal frameworks based on social accounting matrices (SAMs) and detailed water resource accounts for SA but at different time periods. While the Hassan \& Thurlow (2011) study evaluated impacts of recent water policy and macroeconomic reforms on water use and allocation efficiency, as well as on macroeconomic aggregates including rural livelihoods, it did not carry out a detailed assessment of implications for VWT. On the other 
hand, the Lange \& Hassan (2006) study assessed VWT emphasizing structure of trade between SA, Botswana and Namibia but before implementing recent radical water sector and macroeconomic policy reforms. The present work extends the analyses of the two said studies to investigate questions related to whether the evaluated internal reforms have generated positive VWT flows making SA a net importer of VW, and hence tests for the consistency between VWT and internal policy reforms in improving water con-servation and use efficiency. VWT flows are also disaggregated by major trade partners to evaluate implications of recent trade agreements and the potential of regional economic integration within the South African Development Community (SADC) compared to economic cooperation with other major trading blocks for improved water conservation and efficiency in domestic use and allocation.

The next section discusses the relevant key water sector and macroeconomic policy reforms undertaken by SA over the past two decades. Section 3 reviews the literature on VWT and presents earlier findings for SA. Starting from the benchmark analysis of Hassan et al. (2008) based on a 2002 SA Water SAM (SAWSAM) database, Section 4 applies the VWT framework to predicted implications of the SAWSAM model policy simulations for water use and allocation between various domestic uses and international trade. The VWT framework is then employed to derive actual trends in water use from domestic and foreign sources for production and consumption activities in SA over the past decade and analyze possible implications of implemented reforms in Section 5. Section 6 concludes with policy implications and recommendations of the study.

\section{Key water and macroeconomic policy reforms in SA over the last two decades}

To correct for major market and policy distortions in the water sector and the macroeconomy, and to prepare for managing the expected-to-widen gap between national demand for and supply of water, SA has introduced radical policy reforms over the past two decades. This section outlines key reforms of relevance being implemented or intended and their potential implications for water use domestically and through trade.

Key policy distortions dealt with in the SA economy have included the high protection to agriculture through price (subsidies and taxes) and non-price (quotas) measures on water use and allocation, particularly for commercial large-scale farmers, as well as the highly protective foreign exchange and trade regimes (tariffs and export subsidies). Major policy reforms have accordingly been introduced since 1995 to correct these distortions. Of direct relevance is the big move to liberalize agricultural marketing and trade affecting competitiveness of agricultural exports as export subsidies and import tariffs are removed and currency is devaluated (Poonyth et al., 2001; Vink et al., 2002). Moreover, new trade protocols have been negotiated and gradually implemented with SA's main trade partners that are expected to have further implications for the country's trade flows, particularly with the European Union (EU) and SADC (McCarthy, 2010). Other important macroeconomic changes with potentially big impacts on demand and competition for water, particularly with irrigation agriculture, are plans for significant expansions in the services and industrial sectors under the Accelerated and Shared Growth Initiative for SA - Asgisa - accompanied with rapid urbanization over the coming two decades.

At the same time, the National Water Policy (NWP) adopted in 1997 introduced radical shifts in water management in SA (DWAF, 1998), impacts of which have already been felt in many segments of the country's agricultural sector. Major elements of the water sector reforms introduced under the NWP included removal of price subsidies, compulsory licensing, and promotion of water trade to improve efficiency in water use and allocation as well as new institutions (e.g. catchment management agencies 
(CMAs) and water user associations (WUAs)) for decentralized and more inclusive water management. However, in spite of the considerable efforts and high hopes placed on realizing major benefits from implementing decentralized water management, 16 years after the launch of the National Water Act (NWA), only two CMAs have been established and are operational so far, and many WUAs are struggling to function under the current complex water policy reform situation in SA (DWA, 2011, 2013; Shreiner \& Hassan, 2011).

The economy-wide implications of these policy reforms have been evaluated by few studies, the most recent of which is that of Hassan et al. (2008), which traced impacts of a select set of scenarios combining water sector reforms with key elements of the above-outlined macroeconomic adjustments, from their direct influences on efficiency of water allocation between competing domestic users at different regions within the country to their macroeconomic manifestations. Among the key predictions of the employed SAWSAM are shifts of water and land resources from low to high value crops within the irrigation sector, which currently uses more than $60 \%$ of total water (Hassan et al., 2008). One important implication of direct relevance to VWT concerns is the fact that the high value agricultural activities attracting water and land resources under the liberalized water and trade regimes scenarios are the high value field (maize, wheat, and soybean) and horticultural (citrus, etc.) crops that are both water intensive and also largely export oriented (Hassan et al., 2008). The cited work, however, while generating model predictions of likely impacts on exports and imports, did not pursue detailed assessment of VWT implications. More importantly, impacts of the evaluated policies captured changes in export and import total flows only with no disaggrega-tion of source and destination regions of these flows. In the following sections, our study extends the said SAWSAM analyses to explore links between liberalizing water allocation and trade and flows of VW in trade between SA and its partners.

\section{The VWT literature}

Analysis of trade in VW represents a recent response to the increased pressure on water resources globally and in water stressed regions (Allan, 2001; Hoekstra \& Hung, 2005; Novo et al., 2009). The idea of VWT or 'embedded water' emerged from Allan (1993) when he argued that water-poor countries (i.e. Middle East and Mediterranean countries) could relieve the pressure on their domestic water use by importing water-intensive products instead of using their own scarce water resources to produce such products. Although the analysis of VWT was applied to industry and livestock, its main focus has usually been the agricultural sector (Wichelns, 2001; Hoekstra \& Hung, 2002; Yang \& Zehnder, 2002; Chapagain \& Hoekstra, 2003, 2007, 2011; Chapagain et al., 2006; Yang et al., 2006; Zeng et al., 2011; Zhang et al., 2011; Hoekstra, 2012) as it consumes more than $80 \%$ of global water resources. The total annual international VW flows have been estimated at more than 1,000 billion $^{1} \mathrm{~m}^{3}$ (Chapagain \& Hoekstra, 2003; Zimmer \& Renault, 2003), more than 61\% of that is attributed to trade in agricultural products (Chapagain \& Hoekstra, 2003). The USA, China, Brazil, Australia, Canada, Argentina, Germany and India are the major exporters of VW in the world, while water-poor countries in the Middle East and North Africa, as well as Japan, Italy, South Korea and Sri Lanka, remain the principal VW importers (Chapagain \& Hoekstra, 2003).

\footnotetext{
${ }^{1}$ One billion $=1 \times 10^{9}$.
} 
Most VWT studies were based on computing only direct water embodied in the production of exported (imported) goods but did not account for the indirect use of water in the rest of the value chain. Total water used in production and in post-production phases (i.e. storage, post-harvesting processing, and transport) is a more accurate measure of VWT. This is particularly important for products that require more water in post-harvest than during production process (Velazquez, 2006). To overcome such limitations, different studies have used frameworks such as input-output (I-O) and SAM models to evaluate VWT based on both direct and indirect water use in the supply chain, as they allow for calculation of backward and forward multipliers of indirect water use. I-O tables have been used by Guan \& Hubacek (2007) to analyze VWT flows between hydro-economic regions in China and found that although north China is a water-scarce region, it paradoxically produces and exports water-intensive products and imports non-water-intensive commodities. Similarly, Mubako et al. (2013), employing an I-O framework, revealed that California, while relatively more water stressed, is a net exporter of water to the rest of the USA. These results confirm the argument made earlier that other factors could be more important determinants of comparative advantage and trade specialization than water endowment and hence have stronger influence on patterns of VWT. Another I-O study in China by Zhang et al. (2011) analyzed the water footprints and VWT of the city of Beijing in China revealing very high intra-regional VW flows between Beijing and other districts, particularly Heibi district being the main VW contributor to Beijing. Similar studies in Spain employed the I-O framework to trace movements of water across different sectors in response to changes in final demand (Velazquez, 2006; Novo et al., 2009; Llop, 2013). These studies demonstrated the importance of considering both direct and indirect water use along the entire supply chain.

In the South African context, few studies related to VW trade have been conducted. Although not using an I-O analysis, Hoekstra \& Hung (2005) quantified VWT of many countries around the world including SA, between 1995 and 1999 taking into account national water needs and water resources availability. The Hoekstra \& Hung (2005) study also estimated 22\% water dependency (the level to which the country relies on foreign water resources ${ }^{2}$ ) for SA computed as the ratio of net VW imports to total national water appropriation. Another study by Chapagain \& Hoekstra (2003) found SA to be a net importer of water in both crop and livestock foreign trade at $4,369.3 \times 10^{6}$ and $978.3 \times 10^{6} \mathrm{~m}^{3} /$ year through each, respectively. Dabrowski et al. (2009) found maize exports to be the main driver of VW outflows.

While I-O models account for indirect water use within the inter-industry intermediate input transactions matrix, they generally do not include water consumption and transactions in final demand sectors. Lange \& Hassan (2006) extended the I-O analysis to an SAM model to evaluate bilateral VWT between SA, Botswana, and Namibia distinguishing between direct and total water requirements including domestic water use for final consumption. Their findings indicate that SA is a net exporter of VW at the rate of 1,779 million $\mathrm{m}^{3}$ for the year 1998, which is in line with findings of Chapagain \& Hoekstra (2003). This study, however, was carried out before key water policy and macroeconomic reforms were implemented, and hence could only speculate on potential impacts of those adjustments on VWT. In the next section, we apply the Lange \& Hassan (2006) methodology to assess the VWT implications of the simulated model predictions of impacts of internal water policy reforms evaluated in Hassan et al. (2008).

\footnotetext{
${ }^{2}$ This study did not distinguish between water resources managed under trans-boundary agreements and those not under such regulation.
} 
We then extend the analysis to investigate how trends in VWT flows over the past decade have responded to internal reforms using actual trade statistics for SA. Flows of VW since 2002 are disaggregated by major source and destination regions trading with SA. We specifically consider, separately, SA's trade flows with the following five regions: SADC, rest of Africa, EU, Asia, and the Americas.

\section{Implications of the SAWSAM model simulated policy reforms for VWT}

In this section, we compute VW flows between SA and its partners to evaluate the implications for VWT of recent water related policy reforms predicted by the SAWSAM model simulations of Hassan et al. (2008) based on a benchmark of available data for the 2002 base year. We employ in this and subsequent sections a methodology commonly used to compute flows of water embodied in commodities domestically produced or imported for use within the country or exported to trade partners. The employed methodology is detailed in Lange \& Hassan (2006) and described briefly below. We calculate total (final) water use (absorption) within an economy $(W)$ as the sum of water used $\left(W_{i}\right)$ in domestic production activity $i\left(Q_{i}^{\mathrm{D}}\right)$ minus water embodied in the portion of domestic output exported to other countries $\left(Q_{i}^{\mathrm{E}}\right)$ plus $\mathrm{VW}$ contents in imported goods $\left(Q_{i}^{\mathrm{M}}\right)$ plus water used by households and others for final consumption $\left(W^{\mathrm{H}}\right)$.

$W=\sum_{i} W_{i}+W^{\mathrm{H}}$

where

$W_{i}=A_{w}^{\mathrm{D}} \times\left(Q_{i}^{\mathrm{D}}-Q_{i}^{\mathrm{E}}\right)+A_{w}^{\mathrm{M}} \times Q_{i}^{\mathrm{M}}$

$A_{w}^{\mathrm{D}}$ and $A_{w}^{\mathrm{M}}$ define the total water input requirements' coefficients matrix for domestic production and imports, respectively. Accordingly, VW contained in exports $\left(W_{i}^{\mathrm{E}}\right)$ and in imports $\left(W_{i}^{M}\right)$ of commodity $i$ are calculated as follows:

$W_{i}^{\mathrm{E}}=A_{w}^{\mathrm{D}} \times Q_{i}^{\mathrm{E}} \quad$ and $\quad W_{i}^{\mathrm{M}}=A_{w}^{\mathrm{M}} \times Q_{i}^{\mathrm{M}}$

And hence net water exports (imports) $\left(W^{\mathrm{N}}\right)$ is the sum of net water exports (imports) in product $i$ $\left(W_{i}^{\mathrm{N}}\right)$ over all final goods as follows:

$W^{\mathrm{N}}=\sum_{i} W_{i}^{\mathrm{N}}=\sum_{i}\left(W_{i}^{\mathrm{E}}-W_{i}^{\mathrm{M}}\right)$

We start analysis in this section by employing the above-described methodology to calculate VWT for the baseline year 2002. The data employed for these calculations were based on the SAWSAM (Hassan et al., 2008) in which demand for irrigation water was endogenously determined as a factor of production into irrigation crop production ${ }^{3}$. Non-agriculture water use, on the other hand, was treated as an intermediate input provided by a water distribution utility activity with a fixed tariff system. The SA water

\footnotetext{
${ }^{3}$ The SAWSAM employed real-time measures of actual water use by the various agricultural activities modelled combined with national statistics on consumptive water use from StatsSA supply and use tables for non-agricultural users.
} 
Computable General Equilibrium (CGE) model split non-agriculture users into two sectors: (1) heavy industries such as mining, energy, and large industrial establishments; and (2) light industry and house-holds, as two different tariff schemes are applied to each. Expenditure on water use by these sectors as reported in the StatsSA (2002) supply-use tables were then employed to calculate water use per Rand of output, given tariffs charged for that year. The Lange \& Hassan (2006) study-based calculations of water contents of traded commodities on water accounts available to that study for the trading partners considered in the analysis, namely Botswana and Namibia. This study, however, for lack of such data con-sidered water contents, directly and indirectly used for domestic production of traded commodities for both exports and imports. This meant that our study considered water saved from not producing imported goods domestically to represent the actual opportunity cost of saving national water required for domestic pro-duction by alternatively importing such goods from outside the country. This was applied to all imports into SA from many parts of the world covering, as mentioned earlier, five blocks of major trade partners. Results of VWT calculations presented in Table S1 (available online at http://www.iwaponline.com/wp/017/142.pdf) show that in 2002, SA was a net exporter of water $\left(1.69\right.$ billion $\left.\mathrm{m}^{3}\right)$ to the rest of the world (ROW) mainly through horticultural crops, which exported a net total of 2.53 billion $\mathrm{m}^{3}$ followed by the services sector with 0.75 billion $\mathrm{m}^{3}$. Manufactured goods are the main VW importer $\left(1.3\right.$ billion $\left.\mathrm{m}^{3}\right)$. A c c o r d i g t o T a b l e $\mathrm{S} 1 \mathrm{a} \mathrm{n} \mathrm{d} \mathrm{a} \mathrm{s} \mathrm{s} \mathrm{o} \mathrm{c} \mathrm{i} \mathrm{a} \mathrm{t} \mathrm{e} \mathrm{d} \mathrm{Figures} 1$ and 2, it is clear that agricultural

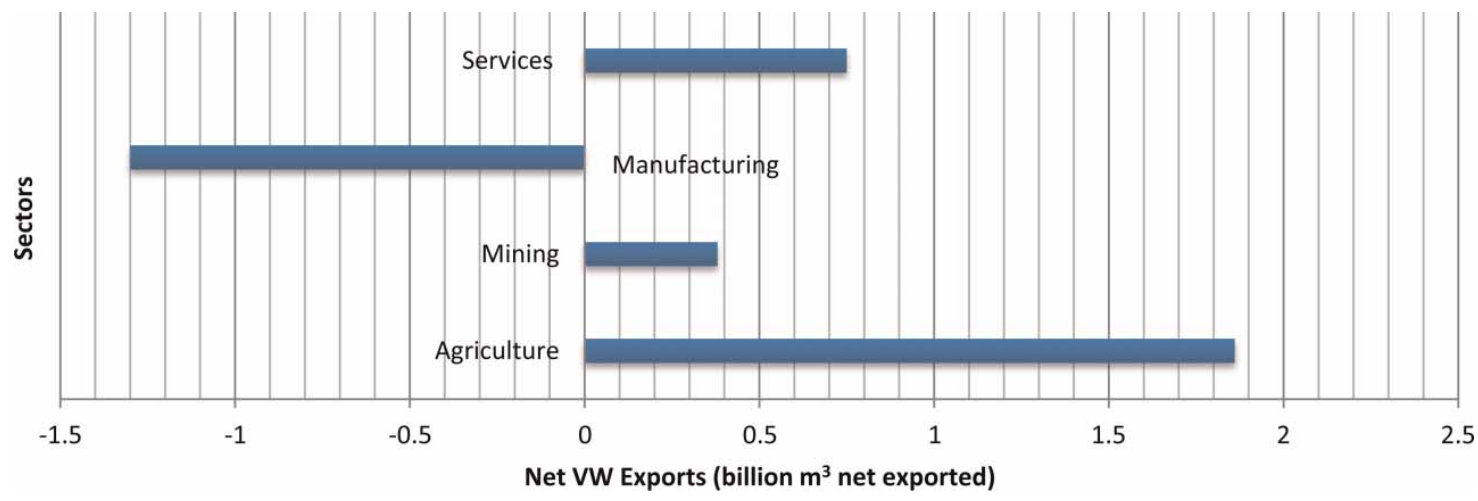

Fig. 1. Net virtual water exports by sectors in South Africa (2002).

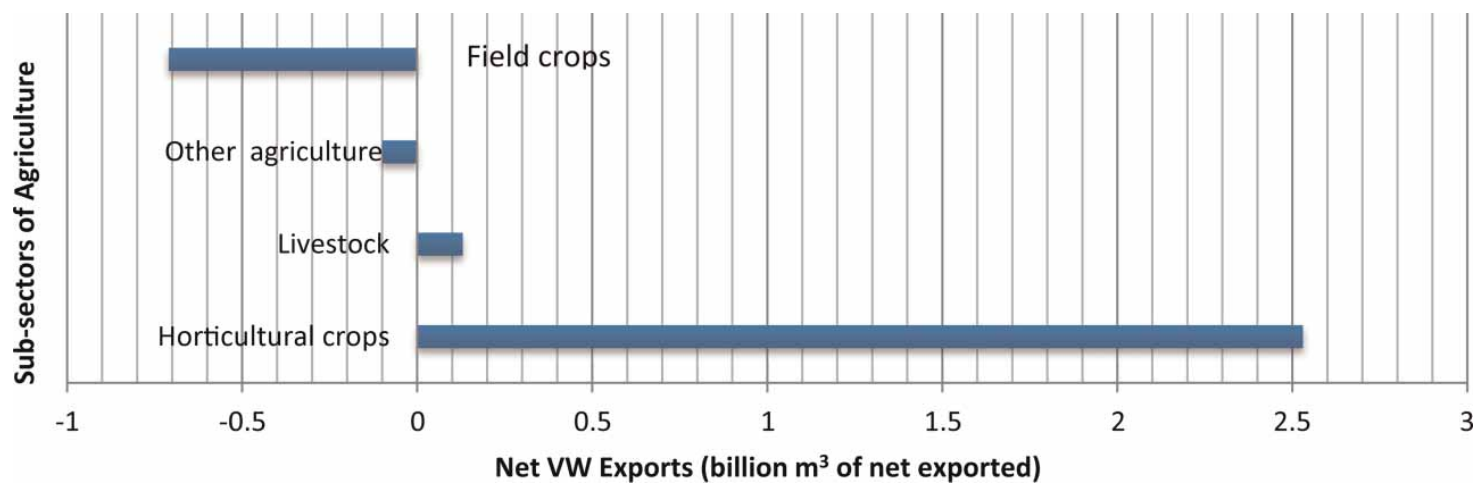

Fig. 2. Net virtual water exports by sub-sectors of agriculture in South Africa (2002). 
exports are the major source of water exports, particularly from horticulture, which contributes almost $80 \%$ of the total VWT in exported agricultural goods. The opposite, however, is true with field crops, which contribute two-thirds of total water in agricultural imports.

We examine in the rest of the section how VWT is likely to be influenced by the above-mentioned water policy change scenarios simulated by the SA water CGE model of Hassan et al. (2008), which can be summarized as follows:

(1) regional liberalization (LC1), where water allocation is liberalized (quota restrictions relaxed to allow allocation through the market, e.g. economic competitiveness) but only between irrigation agriculture activities within regions (water management areas - WMAs);

(2) national liberalization (LC2), in which water allocation between irrigation agriculture activities not only within each region (WMA) but also water allocation between regions is liberalized;

(3) Scenario 2 above was also evaluated under broader macroeconomic liberalization (full liberalization of water allocation Scenario LC3) allowing market-based allocation of water between agriculture and non-agriculture uses within a rapidly urbanized economy (for more details see Hassan \& Thurlow, 2011).

The implications of the above-described policy scenarios' simulations compared to the baseline in 2002 are summarized in Tables 1 and 2. Liberalizing water allocation between competing irrigation agriculture users within WMAs promoted switching of water and land to expansions in production of high value crops (horticulture crops, mainly citrus fruits and vegetables, and cotton and tobacco) at the expense of field crops (cereal grains, fodder, and sugarcane). This resulted in significant expansion in agricultural exports (31.7\%) primarily from horticulture but also sizeable reductions in exports of field crops and other agricultural products (including livestock, fisheries, and forest). While the composition of the impact of this rather limited change in water policy shows negative influences on nonagricultural sectors, the net effects on gross domestic product (GDP) and total exports were positive but very minor. At the same time, imports, particularly of field crops (cereals), increased except for other agriculture. The consequence of such water policy reform on VWT was a substantial increase in net water exports (NWE) $-79 \%$ to the ROW mainly from horticultural exports (61\% higher) whereas NWE from field crops, other agriculture, and non-agriculture declined (Table 1).

Table 1. Implications of liberalizing regional water allocation between competing agricultural uses within WMA (LC1 Scenario).

\begin{tabular}{|c|c|c|c|c|c|c|c|}
\hline & \multirow[b]{2}{*}{$\%$ Change in GDP } & \multicolumn{2}{|l|}{ Exports } & \multicolumn{2}{|l|}{ Imports } & \multicolumn{2}{|c|}{ Net water exports } \\
\hline & & $\%$ Change & Billion $\mathrm{m}^{3}$ & $\%$ Change & Billion $\mathrm{m}^{3}$ & Billion $\mathrm{m}^{3}$ & $\%$ Change \\
\hline Total effect & 0.03 & 0.31 & 9.903 & 0.35 & 6.873 & 3.029 & 79 \\
\hline Agriculture & 4.48 & 31.73 & 5.076 & 3.9 & 1.820 & 3.256 & 75 \\
\hline Field crops & -3.82 & -8.81 & 0.538 & 5.45 & 1.371 & -0.833 & 17 \\
\hline Horticultural crops & 26.41 & 55.38 & 4.351 & 1.8 & 0.275 & 4.076 & 61 \\
\hline Other agriculture & -0.31 & -14.84 & 0.187 & -3.35 & 0.174 & 0.013 & 57 \\
\hline Non-agriculture & -0.18 & -0.88 & 4.827 & 0.27 & 5.054 & -0.226 & 33 \\
\hline$\%$ Food processing & & -1.14 & 0.129 & 0.41 & 0.100 & 0.028 & -6 \\
\hline
\end{tabular}

Source: Authors' calculations based on the South Africa 2002 Water SAM (Hassan et al., 2008). 
Table 2. Implications of liberalizing national water allocation between regions (LC2) and all competing uses (LC3).

\begin{tabular}{|c|c|c|c|c|c|c|c|c|c|c|}
\hline & \multirow{2}{*}{\multicolumn{2}{|c|}{$\begin{array}{l}\% \text { Change in } \\
\text { GDP }\end{array}$}} & \multirow{2}{*}{\multicolumn{2}{|c|}{$\begin{array}{l}\% \text { Change in } \\
\text { exports }\end{array}$}} & \multirow{2}{*}{\multicolumn{2}{|c|}{$\begin{array}{l}\% \text { Change in } \\
\text { imports }\end{array}$}} & \multicolumn{4}{|c|}{ Net water exports } \\
\hline & & & & & & & \multicolumn{2}{|l|}{$\mathrm{LC} 2$} & \multicolumn{2}{|l|}{ LC3 } \\
\hline & $\mathrm{LC} 2$ & LC3 & $\mathrm{LC} 2$ & LC3 & $\mathrm{LC} 2$ & LC3 & Billion $\mathrm{m}^{3}$ & $\%$ Change & Billion $\mathrm{m}^{3}$ & $\%$ Change \\
\hline Total effect & 0.01 & 0.12 & 0.36 & -0.06 & 0.4 & -0.07 & 2.469 & 46 & 1.694 & 0.24 \\
\hline Agriculture & 5.43 & -6.37 & 38.43 & -6.21 & 4.76 & -13.32 & 3.161 & 70 & 1.868 & 0.43 \\
\hline Non-agriculture & -0.24 & 5.79 & -10.41 & 0.17 & 0.3 & 0.23 & -0.692 & -307 & -0.174 & 2.35 \\
\hline
\end{tabular}

Source: Authors' calculations based on the South Africa 2002 Water SAM (Hassan et al., 2008).

LC2 refers to liberalization Scenario 2 in which water allocation both between competing agricultural uses and between regions (i.e. across WMA) is liberalized.

LC3 refers to liberalization Scenario 3 where water allocation not only between agricultural activities but also between agriculture and non-agriculture uses as well as allocation of water between regions (i.e. across WMA) is all liberalized.

The impacts of further liberalization of water markets nationally (LC2) and to non-agricultural competitors (LC3) are compared in Table 2. The contribution of high value agriculture to GDP and exports and consequently NWE has been further enhanced under LC2. The net effect on VWT, however, has been much lower under this scenario mainly due to the large reduction in non-agricultural exports $(10.4 \%)$. Conversely, allowing markets to allocate water between agriculture and non-agricultural users under Scenario LC3 had highly significant gains from induced expansions in non-agricultural activities at the expense of agriculture (and consequently rural livelihoods) but resulted in negligible effect on NWE ( $0.24 \%$ change). These results suggest that the gains in VWT from water policy reforms are more likely under full liberalization of water allocation (i.e. under Scenario LC3). Such gains, however, need to be weighed against what may be considered as socially undesirable results in the distribution of economic gains between agriculture and rural livelihoods, compared to urban-based expansions in non-agricultural activities as well as the likely negative implications for national objectives of food security and self-sufficiency ${ }^{4}$. It is also clear that it is necessary to introduce policies that will enhance likely outcomes of liberalization promoting higher water use efficiency within irrigation agriculture such as increased adoption of more efficient irrigation methods (sprinkler, drip, and other measures that target reducing evaporative losses and do not simply reduce water withdrawal) as water becomes more expensive under wider open competition. Investment in higher water use efficiency and improved competitiveness of dryland agriculture therefore represent the sound economic options for strengthening the capacity to achieve food security objectives as the country strives to lower NWE.

\section{Recent trends in VWT between SA and its major trade partners}

Our estimate of 1.69 billion $\mathrm{m}^{3}$ net water exports by SA in 2002 is only $5 \%$ lower than the 1.78 billion $\mathrm{m}^{3}$ estimated by Lange \& Hassan (2006) for 1998. This section examines whether there is a trend in the country's VWT over the past 12 years using actual trade statistics from StatsSA (Quantec,

\footnotetext{
${ }^{4}$ Find detailed discussion of the implications of these policy scenarios on the overall economic activity, employment, trade, internal fiscal balances, prices, and incomes and livelihoods of rural and urban segments in Hassan \& Thurlow (2011) and Hassan et al. (2008).
} 
2014) for the 2002-2013 period. The analysis also examines the composition of such VWT trends and its direction between SA and its major trade partners, and to what extent these trends followed the CGE model predictions of simulated water policy changes.

As Figure 3 displays, SA has been a net importer of goods and services from the ROW (total imports exceeded its total exports) over the past 12 years. Although this is expected to improve its VWT position causing reduction in net water exports, in fact, net virtual water (NVW) exports were higher during the past 6 years with the exception of 2012 after seeing a declining trend at the beginning of the period (Figure 4). The reasons are clearly seen from the composition of exports and imports. Two main drivers of VW exports have been the steady growth in exports of horticultural and other non-agricultural products (mining and ser-vices) compared to the two major sources of increases in VW imports in crops and manufactured goods (Figures 3 and 4). These trends seem to suggest that water policy liberalization within agriculture has been taking effect, confirming the above model simulation results causing a switch from field crops to hor-ticulture in production and trade. The results also suggest that water allocation regimes between agriculture and non-agricultural uses appear to also be at least partially liberalized, inducing the predicted effect of driv-ing large growth in non-agricultural exports other than manufacturing, as the share of manufactured goods in exports continued to decline throughout while its share in imports remained very high at above $75 \%$ (Table S2, available online at http://www.iwaponline.com/wp/017/142.pdf). Net VWT in manufactured pro-ducts, however, together with trade in crops, was a major offsetting factor to the negative impacts of growth in horticultural exports (Table S3, online at http://www.iwaponline.com/ wp/017/142.pdf). A t th e s a m e ti m e, the country kept growing its net exports of other non-agricultural products, which became a major source of net VW exports in recent years reaching more than 4 billion $\mathrm{m}^{3}$ by 2013 (Table S3).

We examine in the following section destinations and origins of trade flows with SA. Africa clearly enjoys the smallest share of SA's foreign trade compared to the USA and the EU on one hand, and Asia and the ROW as a third destination region (Table S5, online at http://www.iwaponline.com/wp/ 017/142.pdf). Africa's share, however, seems to be growing slowly in both exports and imports (Figure 5). SADC block countries continued to be the main partner in Africa with a very high share in total trade flows

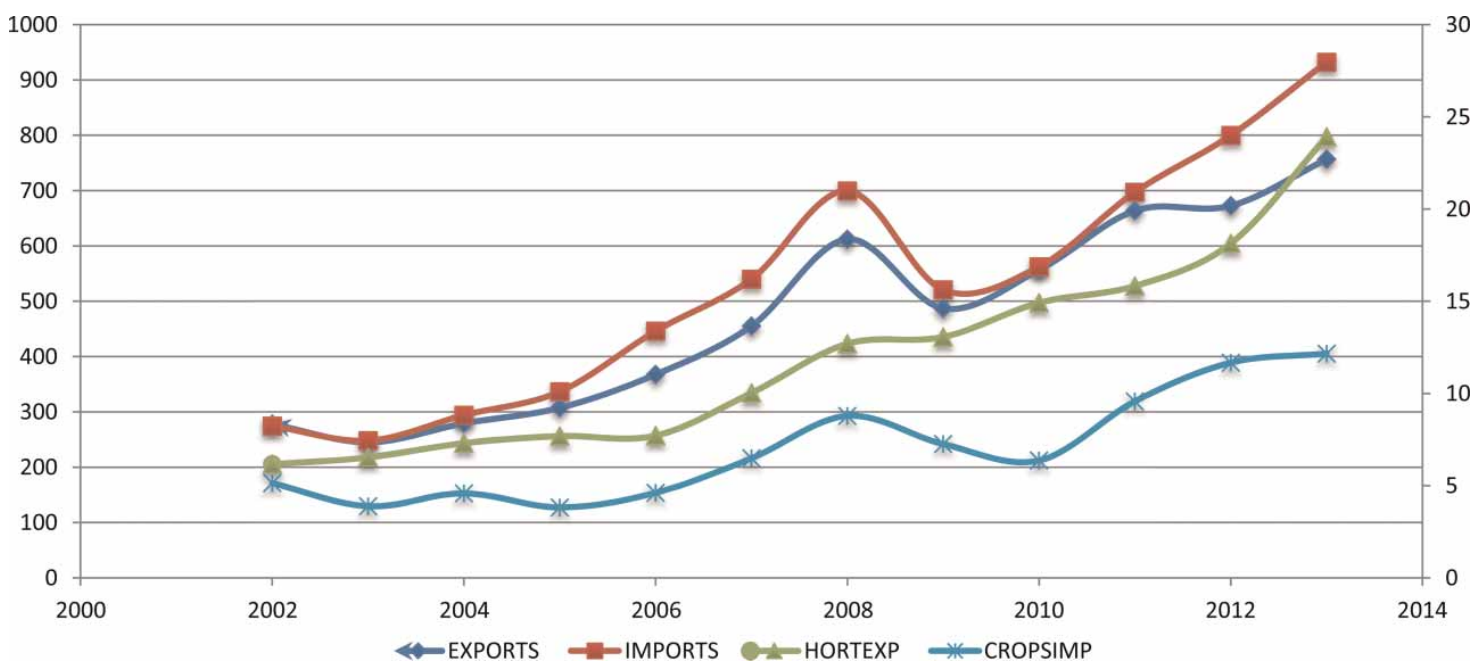

Fig. 3. International trade with South Africa (2002-2013 exports and imports in ZAR billion deflated). Source: Authors' calculations. 


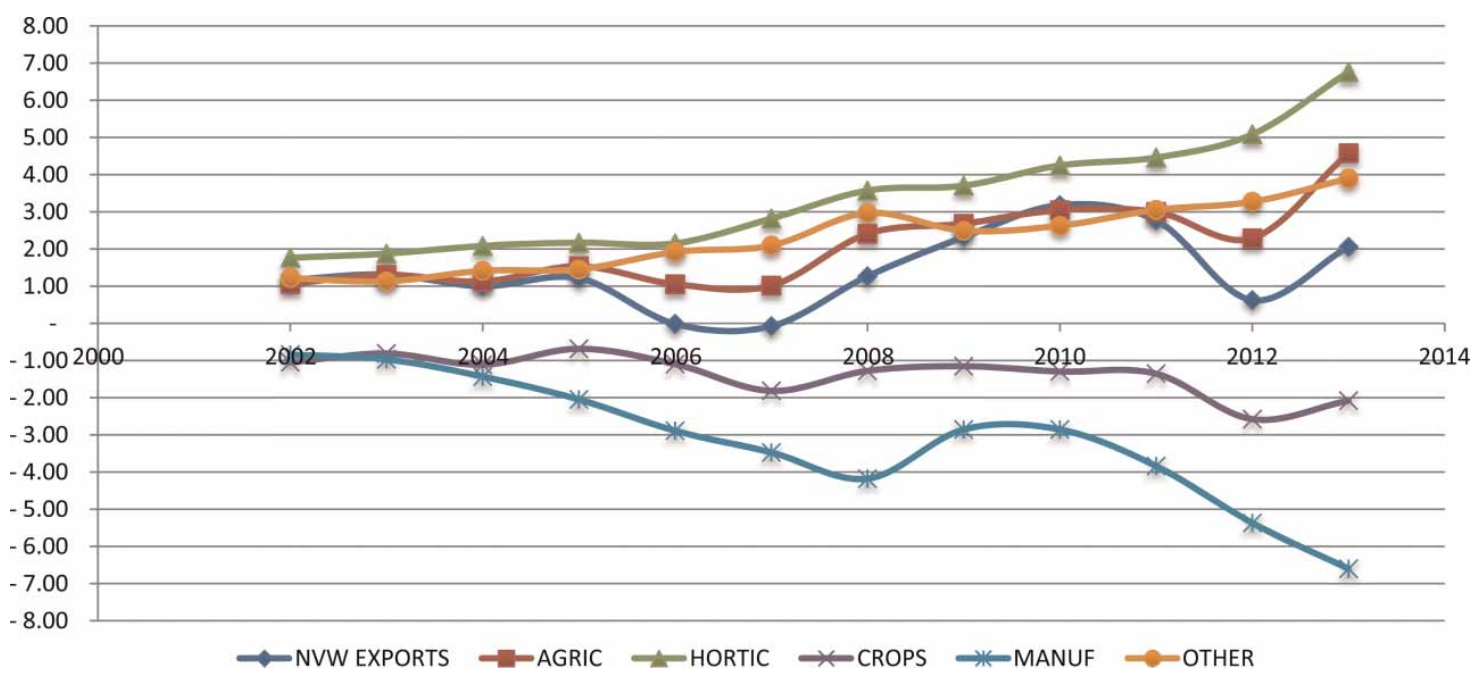

Fig. 4. South Africa's net virtual water trade (net VW exports) trends in billion $\mathrm{m}^{3}$ (2002-2013). Source: Authors' calculations.

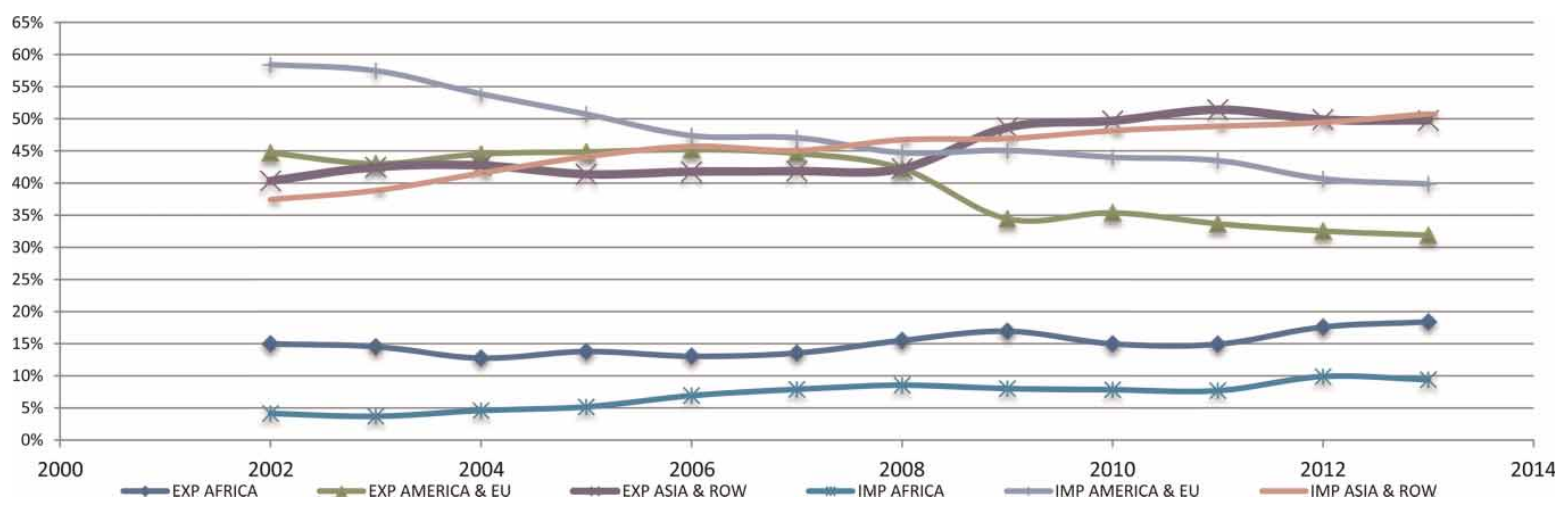

Fig. 5. Destination and origin of South Africa trade flows (shares of exports and imports 2002-2013). Source: Calculated using Quantec (2014) Easy International Trade database.

within Africa (about $70 \%$ of exports to, and more than $50 \%$ of imports from Africa - Table S4, online at http://www.iwaponline.com/wp/017/142.pdf). SA appears to be switching its trading efforts away from the USA and EU to Asia and ROW in both exports and imports. This has become particularly significant since 2008 (Figure 5). Possible causes of these trends could be more favorable trade agreements and terms within Africa and with Asia and ROW compared to the USA and EU. This may be attributed to the recent efforts to strengthen economic cooperation with the BRIC (Brazil, Russia, India, and China) countries where the bulk of SA's trade flows go outside the USA and EU regions.

Trends in destination and origin of foreign trade in selected commodities shown above to be key drivers of NVW trade indicate that Asia and ROW is clearly the major destination for horticultural exports from SA, maintaining a share of above $85 \%$ over the past 12 years (Table S5). Exports of horticultural produce by far exceed (more than double) imports from the Asia and ROW region (mainly BRIC countries) into $\mathrm{SA}$, making this region the main importer of VW from SA given that horticultural produce has the highest 
VW content. The reverse, however, can be said about trade in crops with Africa where SA's exports dropped dramatically from a high share of $87 \%$ to about $25 \%$ by 2013 (Table S5). Nevertheless, the rest of Africa remained a net importer of water in agricultural products due to the offsetting growth in horticultural and other agricultural exports (find more details of NVW exports in Table S6, online at http:// www.iwaponline.com/wp/017/142.pdf).

Although SA shifted its exports of crops from Africa to Asia and ROW, it remains a net importer of VW in agricultural products from the BRIC region due to the large NVW content of horticultural and other agricultural exports to this region (Tables S5 and S6). The Asia and ROW region also continued to be the major source of NVW imports into SA in flows of non-agricultural products as it accounts for more than $90 \%$ of this category's imports, which is about double SA's exports of the same to that region (Table S5). The importance of the USA and EU as trade partners seems to be declining over time in almost all commodity groups except for a large jump over the past 3 years in crops exports from SA (Table S5). VW in agricultural exports particularly from horticulture to Asia and ROW (more than 80\%) and non-agricultural goods (NONAGOZR) to non-BRIC regions (Africa, the USA, and EU) clearly dominates the steadily growing VW in imports of non-agricultural goods, especially from Asia and ROW (NONAGASIA in Figure 6 and Table S6).

\section{Summary and conclusions of the study}

This study extended the analyses of two recent research efforts (a water CGE model and an earlier work on VWT) to investigate the extent to which water sector policy and trade reforms in SA have been complementary or conflicting in improving the country's VWT position and domestic water use and allocation efficiency. The study applied an economy-wide approach to derive net VWT flows between SA and its major trade partners to evaluate implications of recent trade agreements and the

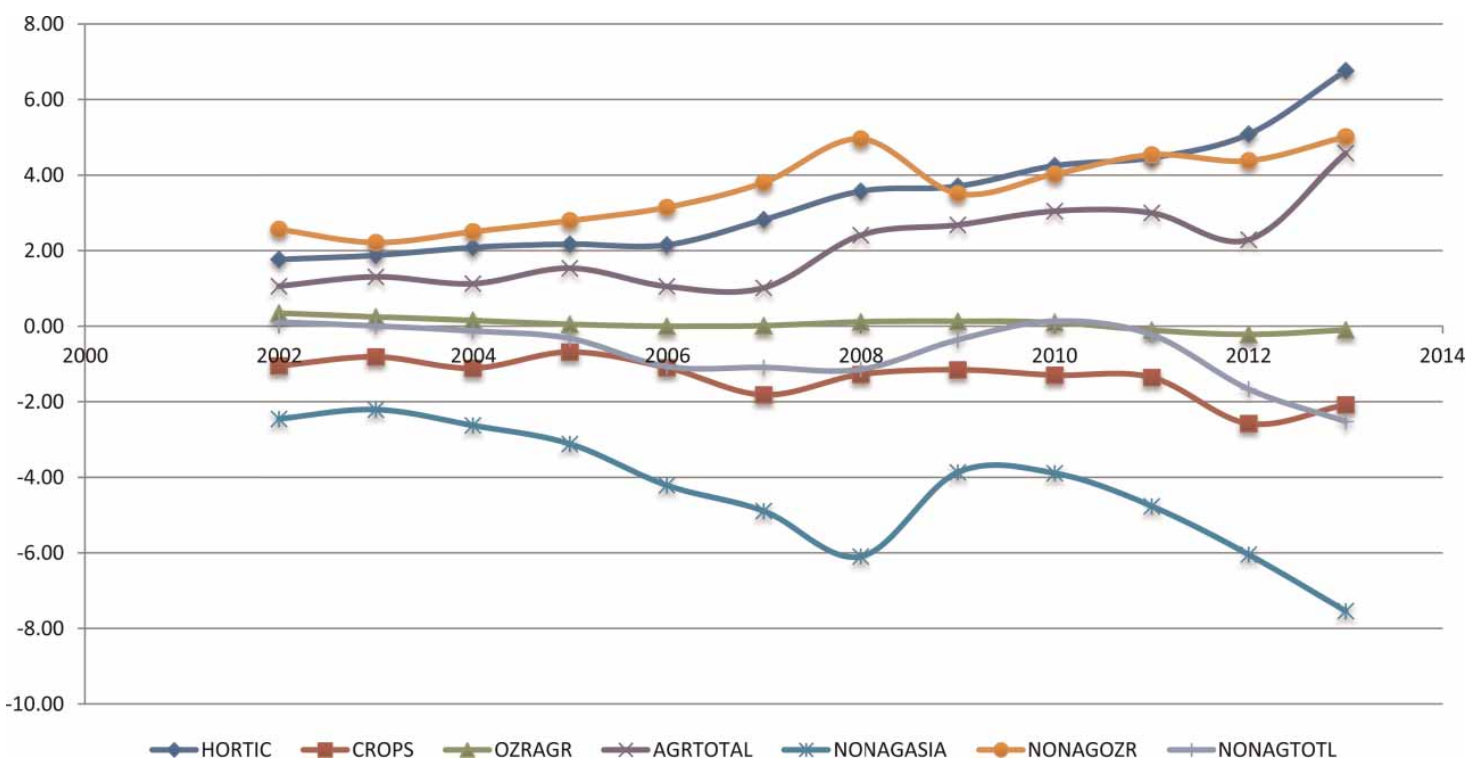

Fig. 6. South Africa's net virtual water exports of key commodities and partners in billion $\mathrm{m}^{3}$ (2002-2013). Source: Authors' calculations. 
potential of regional economic integration within SADC compared to economic cooperation with other major trading blocks (e.g. EU, Asia, etc.). In the baseline year, 2002, agriculture was the major source of water exports mainly in horticultural exports (contributing 80\%) compared to field crops, which contributed, in an opposite direction, to two-thirds of total VW in agricultural imports.

The CGE model simulations of water policy liberalization reforms predicted significant impacts on water allocation within agriculture away from field crops to higher value horticultural products. The consequence of such water policy reform was a substantial increase in VW exports of $79 \%$ compared to the baseline solutions. These negative impacts on VWT (i.e. higher VW exports) were significantly reduced under broader liberalization of water markets at the national level (i.e. allowing markets to allocate water between agriculture and non-agricultural uses). This was due to the induced expansions in non-agricultural activities at the expense of agriculture (and consequently rural livelihoods) but resulted in negligible effect on NVW exports ( $0.24 \%$ change).

Analysis of actual trade data revealed that SA has been a net importer of goods and services over the past 12 years. This, however, did not result in reductions in NW exports but, on the contrary, NW exports were higher during the past 6 years. Reasons are clearly seen from the composition of exports and imports. Two main drivers of VW exports have been the steady growth in exports of horticultural and other non-agricultural products compared to the two major sources of increases in VW imports in crops and manufactured goods.

An examination of the direction and composition of trade flows between SA and its trade partners indicate that Africa (primarily SADC countries) continues to receive the smallest share of SA's foreign trade compared to other regions (i.e. the USA, EU, and Asia and ROW). SA appears to be switching its trading efforts away from the USA and EU to Asia and ROW in both exports and imports. This may be due to the favorable trade agreements and terms attributed to recent efforts to strengthen economic cooperation with the BRIC countries where the bulk of SA's trade flows. NVW exports particularly of horticultural products to BRIC countries (Asia and ROW) and non-agricultural goods to non-BRIC regions (Africa, the USA, and EU) seem to clearly dominate the steadily growing NVW in imports of non-agricultural goods, especially from Asia and ROW making SA a net exporter of VW in recent years.

These trends seem to suggest that water policy liberalization within agriculture has been taking effect, confirming predictions of the economy-wide model simulation results causing a switch from field crops to horticulture. The results also suggest that water allocation regimes between agriculture and nonagricultural uses appear to also be at least partially liberalized inducing the predicted effect of driving large growth in non-agricultural exports (other than manufacturing), which became a major source of net VW exports in recent years reaching more than 4 billion $\mathrm{m}^{3}$ by 2013. The share of manufactured goods in exports continued to decline, however, and SA became more dependent on imports of manufactured goods.

These results suggest that the gains in VWT from water policy reforms are more likely under full liberalization of water allocation. Such gains, however, need to be weighed against what may be considered as socially undesirable results in the distribution of economic gains between agriculture and rural livelihoods compared to urban-based expansions in non-agricultural activities, as well as the likely negative implications for national objectives of food security and self-sufficiency. It is also clear that it is necessary to introduce policies that will enhance likely outcomes of liberalization promoting higher water use efficiency within irrigation agriculture, such as increased adoption of more efficient irrigation methods that aim to reduce evapotranspiration and not simply reduce water withdrawal as water becomes more expensive under wider open competition (e.g. when return flows are an important component of basin-wide hydrology). Investment in higher water use efficiency and improved 
competitiveness of dryland agriculture therefore represent sound economic options for strengthening the capacity to achieve food security objectives as the country strives to lower NWE.

\section{References}

Allan, J. A. (1993). Fortunately there are substitutes for water otherwise our hydro-political futures would be impossible. In: Overseas Development Administration (ODA), Priorities for Water Resources Allocation and Management. ODA, London, pp. 13-26.

Allan, J. A. (2001). Virtual water - economically invisible and politically silent: a way to solve strategic water problems. International Water and Irrigation, November 2001, pp. 39-41.

Chapagain, A. K. \& Hoekstra, A. Y. (2003). Virtual water trade: a quantification of virtual water flows between nations in relation to international trade of livestock and livestock products. In: Virtual Water Trade Proceedings of the International Expert Meeting on VWT. Hoekstra, A. Y. (ed.). UNESCO - IHE Institute for Water Education, Delft, The Netherlands.

Chapagain, A. K. \& Hoekstra, A. Y. (2007). The water footprint of coffee and tea consumption in the Netherlands. Ecological Economics 64, 109-118.

Chapagain, A. K. \& Hoekstra, A. Y. (2011). The blue, green and grey water footprint of rice from production and consumption perspectives. Ecological Economics 70, 749-758.

Chapagain, A., Hoekstra, A. \& Savenije, H. (2006). Water saving through international trade of agricultural products. Hydrology and Earth System Sciences 10, 455-468.

Dabrowski, J. M., Murray, K., Ashton, P. J. \& Leaner, J. J. (2009). Agricultural impacts on water quality and implications for virtual water trading decisions. Ecological Economics 68, 1074-1082.

Dinar, A., Rosegrant, M. W. \& Meinzen-Dick, R. (1997). Water Allocation Mechanisms: Principles and Examples. Policy Research Working Paper Series 1779, The World Bank, Washington, DC, USA.

DWA (Department of Water Affairs) (2011). Executive Business Cases for Institutional Development. Institutional Reforms and Realignment Programme, Government Printers, Pretoria, South Africa.

DWA (Department of Water Affairs) (2013). National Water Resource Strategy: Water for an Equitable and Sustainable Future. Government Printers, Pretoria, South Africa.

DWAF (Department of Water Affairs and Forestry) (1998). Republic of South Africa (RoSA), National Water Act, Act 36 of 1998.

Guan, D. \& Hubacek, K. (2007). Assessment of regional trade and virtual water flows in China. Ecological Economics 61, $159-170$.

Hassan, R. \& Thurlow, J. (2011). Macro-micro feedback links of water management in South Africa: CGE analyses of selected policy regimes. Agricultural Economics 42(2), 235-247.

Hassan, R., Thurlow, J., Roe, T., Diao, X., Chumi, S. \& Tsur, Y. (2008). Macro-Micro Feedback Links of Water Management in South Africa: CGE Analyses of Selected Policy Regimes. Policy Research Working Paper 4768, The World Bank, Washington, DC.

Hoekstra, A. Y. (2012). The hidden water resource use behind meat and dairy. Animal Frontiers 2, 3 -8.

Hoekstra, A. Y. \& Hung, P. Q. (2002). Virtual Water Trade: a Quantification of Virtual Water Flows between Nations in Relation to International Crop Trade. Value of Water Research Report Series No. 11, UNESCO-IHE, Delft, The Netherlands.

Hoekstra, A. Y. \& Hung, P. Q. (2005). Globalisation of water resources: international virtual water flows in relation to crop trade. Global Environmental Change 15, 4 5-56.

IWMI (International Water Management Institute) (2007). Water for Food, Water for Life: A Comprehensive Assessment of Water Management in Agriculture. Molden, D. (ed.). Earthscan, London and International Water Management Institute, Colombo.

Konar, M., Dalin, C., Suweis, S., Hanasaki, N., Rinalso, A. \& Rodriguez-Iturbe, I. (2011). Water for food: the global virtual water trade network. Water Resources Research 47, W05520.

Lange, G. M. \& Hassan, R. (2006). International trade and water use. In: The Economics of Water Management in Southern Africa: An Environmental Accounting Approach. Lange, G.-M. \& Hassan, R. (eds). Edward Elgar, Cheltenham.

Llop, M. (2013). Water re-allocation in the input-output model. Ecological Economics 86, 21 -27. 
McCarthy, C. (2010). Reconsidering regional integration in sub-Saharan Africa. In: Supporting Regional Integration in Southern and Eastern Africa. Trade Law Centre for Southern Africa, Stellenbosch, South Africa.

Mill, J. S. (1844). Essay on Some Unsettled Questions of Political Economy. John W. Parker, London.

Mubako, S., Sajal, L. \& Lant, C. (2013). Input-output analysis of virtual water transfers: case study of California and Illinois. Ecological Economics 93, 230-238.

Novo, P., Garrido, A. \& Varela-Ortega, C. (2009). Are virtual water 'flows' in Spain grain trade consistent with relative water scarcity? Ecological Economics 68, 1454-1464.

Poonyth, D., Hassan, R. \& Kirsten, J. (2001). Random coefficients analysis of changes in meat consumption preferences in South Africa. Agrekon 40, 426-437.

Quantec (2014). Easy International Trade Database, Pretoria. Available from: http://www.quantec.co.za.

Ricardo, D. (1815). An essay on the effects of a low price of corn on the profits of stock etc. In: Works and Correspondence of David Ricardo, vol. IV. Sraffa, P. (ed.). Cambridge University Press, Cambridge.

Shreiner, B. \& Hassan, R. (2011). Transforming Water Management in South Africa: Designing and Implementing a New Policy Framework. Springer, London.

Velazquez, E. (2006). An input-output model of water consumption: analysing inter-sectoral water relationships in Andalusia. Ecological Economics 56, 226-240.

Velázquez, E. (2007). Water trade in Andalusia: an alternative way to manage water demand. Ecological Economics 63, 201208.

Vink, N., Tregurtha, N. \& Kirsten, J. (2002). South Africa's changing agricultural trade regime. In: Paper for 2002 Annual Forum of Trade and Industrial Policy Strategies (TIPS).

Wichelns, D. (2001). The role of 'virtual water' in efforts to achieve food security and other national goals, with an example from Egypt. Agricultural Water Management 49, 131-151.

Yang, H. \& Zehnder, A. J. B. (2002). Water scarcity and food import - a case study for southern Mediterranean countries. World Development 30, 1413-1430.

Yang, H., Wang, L., Abbaspour, K. C. \& Zehnder, A. J. B. (2006). Virtual water trade: an assessment of water use efficiency in the international food trade. Hydrology and Earth System Sciences 10, 443-454.

Zeng, Z., Liu, J., Koeneman, P. H., Zarate, E. \& Hoekstra, A. Y. (2011). Assessing water footprint at river basin level: a case study for the Heihe River basin in northwest China. Hydrology and Earth System Sciences 16, 2771-2781.

Zhang, Z., Yang, H. \& Shi, M. (2011). Analyses of water footprint of Beijing in an interregional input-output framework. Ecological Economics 70, 2494-2502.

Zimmer, D. \& Renault, D. (2003). Virtual water in food production and global trade: review of methodological issues and preliminary results. In: Virtual Water Trade Proceedings of the International Expert Meeting on VWT. Hoekstra, A. Y. (ed.). UNESCO - IHE Institute for Water Education, Delft, The Netherlands. 